\title{
Narrativas orais de crianças com desenvolvimento típico de linguagem***
}

\author{
Oral narratives of children with typical language development
}

\author{
Priscila Artioli Cavalcante* \\ Patrícia Pupin Mandrá**
}

\author{
*Fonoaudióloga. Graduanda do Curs \\ de Fonoaudiologia da Faculdade de \\ Medicina de Ribeirão Preto da \\ Universidade de São Paulo (FMRP- \\ USP). Endereço para correspondência: \\ Av. 53, 1138 - Barretos - SP - CEP \\ 14780-480 (prililica@gmail.com). \\ **Fonoaudióloga. Doutora em \\ Linguística e Língua Portuguesa pela \\ Universidade Estadual Paulista Júlio \\ de Mesquita Filho. Docente do \\ Departamento de Oftalmologia, \\ Otorrinolaringologia e Cirurgia de \\ Cabeça e Pescoço da FMRP - USP. \\ ***Trabalho Realizado na \\ FMRP - USP.
}

Artigo Original de Pesquisa

Artigo Submetido a Avaliação por Pares

Conflito de Interesse: não

Recebido em 18.06.2010.

Revisado em 16.09.2010; 14.11.2010.

Aceito para Publicação em 30.11.2010.

\begin{abstract}
Background: development of oral narrative. Aim: to verify narrative and pause duration, number of words and interlocutor's interventions in the oral narratives of children with typical development. Method: this study involved 31 subjects divided into four groups according to age: GI (3:1 to 4:0 years), GII (4:1 to 5:0 years), GIII (5:1 to 6:0 years) and GIV (6:1 to 7:0 years). Samples of spontaneous narrative and narrative based on a book without words were video recorded, transcribed and statistically analyzed using the Fisher's exact test (nonparametric) and the linear regression model with mixed effects. Results: the results of pause duration, narrative duration and number of words were significantly higher for the narrative samples produced using a book than those obtained in the spontaneous narratives ( $\mathrm{p}$-value $<0.01$ ). Regarding the number of interventions, a correlation ( $p$-value $=0.03)$ between age and number of interventions was observed for the book context. It was observed that the number of interventions decrease with age. Conclusion: children presented longer narratives in the book context. However, no significant differences were observed between the age groups. The results of the study also suggest that the interlocutor's interventions become less necessary with the aging process.
\end{abstract}

Key Words: Child Development; Child Language; Narration; Speech-Language Pathology.

\section{Resumo}

Tema: desenvolvimento da narrativa oral. Objetivo: verificar o tempo de narrativa e de pausa, o número de palavras e de intervenções do interlocutor em narrativas orais de crianças com desenvolvimento típico. Método: participaram do estudo 31 crianças divididas em quatro grupos etários: GI (3:1 a 4:0 anos), GII (4:1 a 5:0 anos), GIII (5:1 a 6:0 anos) e GIV (6:1 a 7:0 anos). Amostras de narrativa espontânea e narrativa com livro sem palavras foram coletadas em vídeo, transcritas e analisadas estatisticamente por meio de teste exato de Fisher (não-paramétrico) e modelo de regressão linear com efeitos mistos. Resultados: os valores de tempo de pausa, tempo de narrativa, e o número de palavras no contexto de livro foram significativamente maiores em relação à narrativa espontânea (p-valor < 0,01). Quanto ao número de intervenções, houve correlação $(p$-valor $=0,03$ ) entre idade e intervenção no contexto de livro com diminuição da intervenção na media que aumentou a idade. Conclusão: as crianças apresentaram uma narrativa mais extensa no contexto de relato com livro sem palavras em relação ao contexto de narrativa espontânea, porém, sem diferenças significativas entre as idades. O estudo permitiu ainda concluir que a participação do interlocutor faz-se menos necessária conforme aumenta a idade do narrador. Palavras-Chave: Desenvolvimento Infantil; Linguagem Infantil; Narrativa; Fonoaudiologia.

Referenciar este material como: 


\section{Introduction}

During the language development, the child will understand the semantic, phonological, morphosyntactic and pragmatic rules, including oral narrative to argue, justify and explain $(1,2,3)$. The study of narrative is important for the insertion of the child into the familiar, educational and social contexts $(1,2,4,5)$. A complex network of cognitive and linguistic factors is thought to exist to structure, process, understand and share individual experiences and events interrelated by logical and chronological relationships $(6,7,8,9,10,11)$.

By the second year of life, children begin to explore the narrative of their own experiences by evoking past events and talking about them. In this phase, children do not have all cognitive and linguistic elements to organise the narrative structure and therefore they depend on the interlocutor's intervention in order to contextualise and order the events so that text coherence and cohesion can be achieved $(1,2,4,11,12,13,14,15)$.

By the third year of life, the typically developing children obtain their narrative modelling from the adults $(11,16)$. By the age of 3-4 years, storytelling includes a greater number of sentences concatenated with some narrative markers $(11,12)$. In the fictitious narrative, one can observe the presence of secondary elements and insertion of non-true facts, although adults can sporadically intervene in the child's narrative regarding speech coherence and cohesion $(9,11,17)$.

Between 4:1 and 6 years old, acquisition of narrative text structure is complete $(1,11,12)$ and the children tell coherently known narratives and personal reports and create their own stories in details. Contextualising the interlocutor in terms of player, actions, place and moment in which the facts take place, when they are telling stories with visual support, can add intermediate and non-visible relations (11, 12 , 15). With increase in age and school level as well as cognitive maturation and linguistic development, the child becomes familiarised with the complex narrative structure and consequently the frequency of breaks (pauses and interjections) is decreased, which makes the narrative more complex and elaborated $(4,18,19)$. Children at school age are expected to understand their teacher's explanations, tell and re-tell stories, and interpret them $(14,20)$.

Some authors (4) consider that it is important to produce and understand oral narratives for the child's academic success and socio-emotional well-being. In reviewing the national and international literature, no study was found on narrative time, pause time and number of words and adult interventions during personal storytelling and with visual support.
Therefore, the objective of the study was to verify narrative time, pause time, number of words and interlocutor's interventions in oral narratives of pre-school children with typical language development.

\section{Method}

Research has been approved by the Research Ethics Committee of the Ribeirão Preto School of Medicine Clinic Hospital (HCFMRP-SP) according to protocol number 6001/2007. In addition, authorisation was given by the day-care chief so that the children could participate in the study.

The caregivers of the 31 children selected were informed about the goals and risks of the research, including doubts and signing of an informed consent form. The children were 3-7 years old and were enrolled in the day-care centre, all presenting typical language development that was evaluated by means of a speech therapy screening. The subjects were divided into four age groups, as follows: GI, 3:1 to 4:0 years ( $n=4$, mean age $=3.9$ ); GI, $4: 1$ to $5: 0$ years $(n=8$, mean age $=4.7)$; GIII, $5: 1$ to $6: 0$ years $(n=9$, mean age $=5.9)$; and GIV, 6:1 to $7: 0$ years $(n=10$, mean age $=6.9)$.

The samples of narrative speech were orderly collected in two situations: 1) Visual-supported report: children were asked to report the facts related to the book's illustration by following the verbal command: "Tell me what's going on?" 2) Personal report: The children were asked to report a given fact in their lives in order to begin their narrative speech: "what did you do today?" In both situations, the verbal commands could be reformulated depending on the degree of dependence on the interlocutor as well as topics of interest that had been previously addressed. During sample collection, the investigator intervened only when the pause lasted more than 10 seconds by asking cohesive questions such as, "And then what happened?" These interventions were categorised for statistical application as "no intervention" (N.I) for no intervention, "few interventions (F.I) for 1-3 interventions, and many interventions (M.I) for more than 4 interventions. Such procedures were conducted in 15 minutes, on average, with the samples being recorded in video format with a SONY Handcam HD camera mounted on a tripod towards the child. At the end of the sample collection, the investigator showed the child a trailer of the video in order to reward his or her participation.

The instrument stimulating the visualsupported report was a wordless storybook, "O 
Da-a-Dia de Dadá" (21). The speech samples were collected in a noise-isolated room furnished with child table and chair.

The samples were transcribed by means of earphones, microphone, monitor screen, pen, and paper according to the Study Project of Urban Linguistic Cult Norm transcription protocol (22). The speech samples were listened to twice, with the first transcription concerning linguistic aspects and the second one concerning extra-linguistic aspects. In case of doubts involving a given segment, this was listened to three times and then classified as unintelligible, hypothetical or transcribed.

Pause and narrative times in both speech situations were recorded in seconds. The parameters for narrative time, pause time and total number of words were statistically analysed by using the mixed-effect linear regression model (random and fixed effects). The mixed-effect linear regression models are used for data analysis in which responses are grouped (repeated measurements for the same individual) and the supposed independence between observations within the same group is not adequate (23). On the other hand, categorised interventions by the interlocutor were analysed by means of the Fisher's exact test. This, in turn, is a non-parametric test in which differences between two independent groups are tested in relation to a given variable with only two answers: yes or no, positive or negative, and so on. In addition, this test is particularly adequate for small samples (24).

\section{Results}

Table 1 lists the statistical analysis for narrative and pause times between the groups as well as in relation to the narrative contexts, that is, spontaneous or visually supported. No significant difference in narrative and pause times were found between age groups. However, the mixed-effect linear regression model showed that narrative time with storybook was significantly greater than that made spontaneously for groups GII, GIII and GIV (pvalue $<0.01)$. Pause time was significantly greater during the narrative with storybook in all groups ( $\mathrm{p}$-value $=0.03$ for GI and $\mathrm{p}$-value $<$ 0.01 for others).

Table 2 lists statistical values obtained from the comparison between number of words per age group and narrative situations. The number of words was significantly smaller for spontaneous narrative compared to that using a storybook for groups GIII and GIV (p-value < 0.01 ). No significant difference was found between age groups.

Table 3 shows the frequency of subjects in relation to intervention categories regarding the two narrative contexts analysed according to the Fisher's exact test. With regard to the narrative using a wordless storybook, GI had $25 \%$ of the subjects falling in the N.I. category, 25\% in the F.I category, and $50 \%$ in the M.I. category. In GII, $38 \%$ were in the N.I. category, $50 \%$ in F.I category and $12 \%$ in the M.L. In GIII, $89 \%$ were in the N.I category, with $0 \%$ and $11 \%$ falling in F.I and M.I. categories, respectively. Finally, GIV had $70 \%$ in the N.I. category, $30 \%$ in the F.I. category and $0 \%$ in the M.I. category. With regard to spontaneous narrative, the values were the following: GI had N.I. $=0 \%$, F.I $=100 \%$, and M.I. $=0 \%$; GII had N.I. $=62 \%$, F.I. $=38 \%$, and M.I. $=0 \%$; GIII had N.I. $=56 \%$, F.I. $=44 \%$, and M.I. $=0 \%$, and GIV had N.I. $=60 \%$, F.I. $=$ $30 \%$, and M.I. $=10 \%$. 
TABLE 1. Comparisons for variables "narrative" time and "pause" time.

\begin{tabular}{|c|c|c|c|}
\hline Time & Comparisons & Estima tive** $^{* *}$ & P-value \\
\hline \multirow{16}{*}{ Narrative } & LIVRO (G-I - G-II) & 1.63 & 0.43 \\
\hline & LIVRO (G-I - G-III) & 2.58 & 0.47 \\
\hline & LIVRO (G-I - G-IV) & 4.34 & 0.4 \\
\hline & LIVRO (G-II - G-III) & 0.94 & 0.67 \\
\hline & LIVRO (G-II - G-IV) & 2.71 & 0.46 \\
\hline & LIVRO (G-III - G-IV) & 1.76 & 0.37 \\
\hline & S.N. (G-I - G-II) & 2.51 & 0.22 \\
\hline & S.N. (G-I - G-III) & 2.95 & 0.41 \\
\hline & S.N. (G-I - G-IV) & 4.35 & 0.4 \\
\hline & S.N. (G-II - G-III) & 0.43 & 0.84 \\
\hline & S.N. (G-II - G-IV) & 1.83 & 0.62 \\
\hline & S.N. (G-III - G-IV) & 1.39 & 0.48 \\
\hline & G-I (BOOK - S.N.) & 3.38 & 0.06 \\
\hline & G-II (BOOK - S.N.) & 4.26 & $<0.01 *$ \\
\hline & G-III (BOOK - S.N.) & 3.75 & $<0.01 *$ \\
\hline & G-IV (BOOK - S.N.) & 3.38 & $<0.01 *$ \\
\hline \multirow{16}{*}{ Pause } & BOOK (G-I - G-II) & 0.52 & 0.71 \\
\hline & BOOK (G-I - G-III) & 2 & 0.43 \\
\hline & BOOK (G-I - G-IV) & 3.49 & 0.34 \\
\hline & BOOK (G-II - G-III) & 1.47 & 0.35 \\
\hline & BOOK (G-II - G-IV) & 2.96 & 0.26 \\
\hline & BOOK (G-III - G-IV) & 1.49 & 0.29 \\
\hline & S.N. (G-I - G-II) & 2.09 & 0.15 \\
\hline & S.N. (G-I - G-III) & 2.51 & 0.32 \\
\hline & S.N. (G-I - G-IV) & 3.37 & 0.35 \\
\hline & S.N. (G-II - G-III) & 0.42 & 0.79 \\
\hline & S.N. (G-II - G-IV) & 1.27 & 0.62 \\
\hline & S.N. (G-III - G-IV) & 0.85 & 0.54 \\
\hline & G-I (BOOK - S.N.) & 2.69 & $0.03^{*}$ \\
\hline & G-II (BOOK - S.N.) & 4.26 & $<0.01 *$ \\
\hline & G-III (BOOK - S.N.) & 3.2 & $<0.01 *$ \\
\hline & G-IV (BOOK - S.N.) & 2.57 & $<0.01 *$ \\
\hline
\end{tabular}

Notes: S.N. = spontaneous narrative; BOOK = narrative with storybook; *Signific ant data (p-value ? 0.05); ** Square root transformation was applied to data.

TABLE 2. Comparisons for variable "number of words".

\begin{tabular}{lll}
\hline Comparisons & Estimative*** & P-value \\
\hline BOOK (G-I - G-II) & 2.48 & 0.25 \\
BOOK (G-I - G-III) & 0.36 & 0.92 \\
BOOK (G-I - G-IV) & 1.34 & 0.80 \\
BOOK (G-II - G-III) & -2.12 & 0.37 \\
BOOK (G-II - G-IV) & -1.14 & 0.77 \\
BOOK (G-III - G-IV) & 0.97 & 0.64 \\
S.N.** (G-I - G-II) & 1.12 & 0.60 \\
S.N.** (G-I - G-III) & 1.70 & 0.65 \\
S.N.** (G-I - G-IV) & 1.93 & 0.72 \\
S.N.** (G-II - G-III) & 0.58 & 0.80 \\
S.N.** (G-II - G-IV) & 0.81 & 0.83 \\
S.N.** (G-III - G-IV) & 0.23 & 0.91 \\
G-I(BOOK - S.N.) & 2.31 & 0.19 \\
G-II (BOOK - S.N.) & 0.95 & 0.44 \\
G-III (BOOK - S.N.) & 3.65 & $<0.01 *$ \\
G-IV (BOOK - S.N.) & 2.91 & $<0.01 *$ \\
\hline
\end{tabular}

Notes: S.N. = spontan eous narrative; BOOK = narrative with storybook, *Significant data (p-value ? 0.05), ** Square root tran sformation was app lied to data. 
TABLE 3. Association between age groups and narrative interventions for storybook and spontaneous situations.

\begin{tabular}{|c|c|c|c|c|c|}
\hline \multirow[t]{2}{*}{ Type of narrative } & \multirow[t]{2}{*}{ Group } & \multicolumn{3}{|c|}{ Cat ego ry } & \multirow[t]{2}{*}{ Total } \\
\hline & & N.I. & F.I. & M.I. & \\
\hline \multirow{5}{*}{ Storybook } & G-I & $125 \%$ & $125 \%$ & $250 \%$ & 4 \\
\hline & G-II & $338 \%$ & $450 \%$ & $112 \%$ & 8 \\
\hline & G-III & 8 89\% & $0 \quad 0 \%$ & $111 \%$ & 9 \\
\hline & G-IV & $7 \quad 70 \%$ & $330 \%$ & $0 \quad 0 \%$ & 10 \\
\hline & Total & 19 & 8 & 4 & 31 \\
\hline \multirow{3}{*}{ Spontan eous } & G-I & $0 \quad 0 \%$ & $4100 \%$ & $0 \quad 0 \%$ & 4 \\
\hline & G-II & $562 \%$ & $338 \%$ & $0 \quad 0 \%$ & 8 \\
\hline & G-III & $556 \%$ & $444 \%$ & $0 \quad 0 \%$ & 9 \\
\hline
\end{tabular}

Notes: N.I. = no interven tion; F.I. = few interventions; M.I. = many intervention s, *p-value for relation between category and storybook narrative $=0.03, * *$ p-value for relation between category and spontaneous narrative $=0.20$.

\section{Discussion}

Narrative time was not found to be significantly different between age groups, despite being greater in the situation in which a visual support (wordless storybook) was used, thus suggesting that illustrations and questions to stimulate personal report are important variables. Therefore, the use of illustrations could allow more extensive narratives to be made, whereas spontaneous narrative involves intention, initiative and interest on the part of the speaker in elucidating and communicating linguistically the experience he or she lived (11). At four years old, the non-visible relations existing in the illustrations are already present in child narratives (11, $12,15)$. In order to start a personal report, the question "What did you do today?" was used in this study, considering that children usually talk about routine and family facts and report their own experiences even at 2 years old $(11,12,14,15)$. Situations of group and ludic interactions have been mentioned as promoting increase in time and complexity of the narrative structure (11).

The increased pause time in the storybook narrative seems to be related to cognitive and linguistic gaps, thus evidencing the gradual process of formation of concepts, lexical items and assimilation of syntactic rules for structuring the narrative speech $(6,7,8,9,10,11,18)$. This also might be a strategy for the speaker to get more time to repair the mistakes in the narrative production or even to follow actions such as page changes (18).
The absence of statistical significance in age groups, considering the values for narrative time and pause time, is a finding not corroborated elsewhere, since there are studies $(18,19)$ showing an inversely proportional relation between gradual process of linguistic development and interruption in the narrative speech.

The number of words was significantly smaller in the samples of spontaneous narrative compared to that using visual support for GIII and GIV, thus suggesting again that intention and motivation allied to cognitive and linguistic skills are needed for spontaneous speech. Illustrations also contributed to the construction of story meaning and linguistic structuralisation, since speaker seemed to use the illustration as reference (25). At 3 years old, reports should be composed by simple and complex periods, narrative marker and words with lexical, grammatical and contextual meaning $(11,12)$.

It was found that interlocutor intervention decreases with age, as a higher frequency of subjects in younger age groups (GI and GII) fell in the M.I. category (many interventions) while a lower frequency of subjects in this same age group fell in the N.I. category (no interventions) for visual-supported narrative (wordless storybook) $(\mathrm{p}$-value $=0.03)$. This finding had already been discussed in the literature (11), explaining that adult participation is greater in the beginning of the speech development, whose construction is made on a joint basis, decreasing over time when the cognitive and linguistic skills of the 
children allow them to make their own narratives. With regard to spontaneous narrative, the findings were not significant. In fictitious narrative, for example, it was observed the presence of secondary elements and insertion of non-true contents, although sporadic adult intervention may occur to help make the speech coherent and fluent $(7,9,11)$.

\section{References}

1. Souza APR, Sperb CB. Desempenho narrativo de sujeitos com distúrbio/atraso fonológico. Rev. Cefac. 2009 JulSet;11(3):389-95.

2. Mandrá PP. Processos argumentativos durante a aquisição da linguagem. In: VII Jornada de Fonoaudiologia, 2006, Ribeirão Preto. Anais da VII Jornada de Fonoaudiologia; 2006.

3. Largo M, ZINI TC, Ascencio-Ferreira VJ. A narrativa da criança e do adolescente na deficiência mental. Revista Fonoaudiologia Brasil, Brasília (DF). 2003. junho p. 43-7.

4. Dadalto EV, Goldfeld M. Características comuns à narrativa oral de crianças na pré-alfabetização. Rev. Cefac. 2009 Jan-Mar;11(1):42-9.

5. Mccabe A, Bliss L, Bennett GBM. Comparison of personal versus fictional narratives of children with language impairment. American Journal of Speech-Language Pathology. 2008 May;17:194-206.

6. Vieira AG, Sperb TM. O brincar simbólico e a organização narrativa da experiência de vida na criança, Psicologia: Reflexão e Crítica. 2006;20(1):9-19.

7. Brandão L, Smith V, Sperb TM, Parente MAMP. Narrativas Intergeracionais. Psicologia: Reflexão \& Crítica. 2006;19(1):98-105.

8. Bishop DVM, Norbury CF. Narrative skills of children with communication impairments. Int. J. Lang. Comm. Dis. 2003;38:287-313.

9. Shiro M. Genre and evaluation in narrative development.

J. Child Lang., London. 2003;30:165-95.

10. Vieira AG. Do conceito de estrutura narrativa à sua crítica.in psicologia: reflexão e crítica. 2001;14(3):599608.

11. Perroni MC, O Desenvolvimento do Discurso Narrativo. São Paulo: Martins Fontes; 1992.

\section{Conclusion}

Children have a more extensive narrative within the context of a wordless storybook compared to the spontaneous narrative, although no significant differences were found between age groups. This finding shows that different narrative contexts have influence on their production. Therefore, in the clinical practice, collecting various narrative samples in different situations to compare them may be an efficient procedure for evaluation and diagnosis of the linguistic and narrative aspects as a whole. This study has also allowed us to conclude that interlocutor participation is less needed as the child becomes older.

12. Zorzi JL, Hage ARV. Protocolo de observação comportamental: avaliação da linguagem e aspectos cognitivos. São José dos Campos: Pulso; 2004.

13. Goulart CMT. Histórias de criança: as narrativas de crianças asmáticas no brincar. Psicologia: reflexão e crítica. 2003;16(2):355-65.

14. Artoni AL, Caracterização de narrativas de crianças de 5 e 6 anos: correlações entre episódios e ações. $104 \mathrm{f}$. Dissertação (Mestrado em Distúrbios da Comunicação Humana) - Universidade Federal de São Paulo, São Paulo; 2001.

15. Hickmam M. Capítulo 7 - Organização do discurso e do desenvolvimento da referência à pessoa, espaço e tempo, p. 165-83. in: Fletcher P e Macwhinney BC. Compêndio da linguagem da criança, Porto Alegre: Artes Médicas; 1997.

16. Castilho AT. Descrição, história e aquisição do português brasileiro - Estudos dedicados a Mary Aizawa Kato, Maria Aparecida C. R. Torres Morais,Ruth Elizabeth Vasconcellos Lopes, Sônia Maria Lazzarini Cyrino e Ataliba Teixeira de Castilho (orgs)/ São Paulo: Fapesp,Campinas: Pontes Editores; 2007.

17. Brockmeier JE, Harré R. Narrativa: problemas e promessas de um paradigma alternativo. New School University New York/Freie Universität Berlin 18 Rom Georgetown University Washington, DC/Psicologia: Reflexão e Crítica. 2003;16(3):525-35.

18. Guo L, Tomblin JB, Samelson V. Speech disruptions in the narratives of english-speaking children with specific language impairment. Journal of Speech, Language, and Hearing Research. 2008 jun;51:722-38.

19. Rispoli M, Hadley P. The leading edge: the significance of sentence disruptions in the development of grammar. Journal of speech, language and Hearing research. 2004;44:1131-43. 
20. Westerveld MF e Gillon GT. Oral narrative intervention for children with mixed reading disability. Child Language Teaching and Therapy. 2008;24(1):31-54.

21. Xavier M. O dia-a-dia da Dada. $18^{\mathrm{a}}$ ed. Belo Horizonte: Formato; 1987.

22. Barros DLP. Entre a fala e a escrita: algumas reflexões sobre as posições intermediárias In: Preti D. (org.) Fala e escrita em questão. São Paulo: Humanitas/Projeto NURCSP. 2001 vol. 4.

23. Schall R. Estimation in generalized linear models with random effects. biometrika. 1991;78(4):719-27.
24. GM. Campos, Estatística Prática para Docentes e PósGraduandos. Disponível em: www.forp.usp.br/restauradora/ gmc/gmc livro/gmc livro cap19.html. Atualizada em 19/1/ 2001. Acessada em 11/6/2010.

25. Ramos FB, Panozzo NSP. O processo de construção do sentido em narrativas infantis. In: V Congresso Internacional de Educação: os desafios no processo ensino-aprendizagem, 2004, São Luís. Anais do V Congresso Internacional de Educação. João Pessoa : UFPB - Editora Universitária; 2004. p. 420-420. 